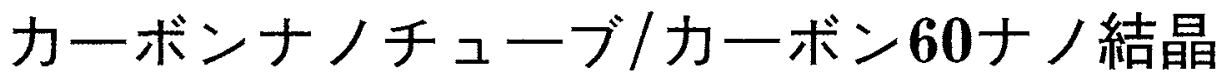 複合体の組織と変形挙動
}

\author{
葛巻 徹 林 卓 哉 ${ }^{\dagger}$ 市野瀬英喜 \\ 宮澤薫一 伊藤邦夫 石田洋一サ
}

東京大学大学院工学系研究科

J. Japan Inst. Metals, Vol. 61, No. 4 (1997), pp. 319-325

\section{Structure and Deformation Behavior of Carbon Nanotubes Reinforced Nanocrystalline C60 Composite}

Toru Kuzumaki, Takuya Hayashi†, Hideki Ichinose, Kun-ichi Miyazawa, Kunio Ito and Yoichi Ishida ${ }^{\dagger \dagger}$

Department of Materials Science, School of Engineering, The University of Tokyo, Tokyo 113

\begin{abstract}
Carbon nanotube reinforced nanocrystalline $\mathrm{C} 60$ was prepared at room temperature by drawing the composite sheathed in silver tube. Fine structures of the composite were examined by high resolution electron microscopy (HREM) and the mechanical properties by conventional tensile tests.

HREM observation shows that carbon nanotubes in the composite are defect free and aligned well in the direction of the wire. The stress-strain curve of the composite wire de-sheathed by evaporation of silver through heat treatment gives approximately 20 times increase in the fracture stress over that of polycrystalline $\mathrm{C} 60$ with higher fracture strain (over 10\%). The fracture surface of the wire shows that nanotubes were pulled out but not fractured.

TEM observation of interface structure of 660 vapor deposited nanotubes as well as pull-out tests were performed of $\mathrm{C} 60$ single crystals vapor-deposited on single high elasticity carbon fibers which have similar surface structure as nanotube to examine the origin of the large elongation of the composite. It has been inferred that shear deformation takes place in the carbon fiber/C60 single crystal interface with little deformation of matrix but without fracture of the fiber and that the pull out was mainly caused by the shear deformation, which was probably made possible by a weak interaction between graphitic basal plane and $\mathrm{C} 60$.

The experiments lead us to a new concept of a ductile $\mathrm{C} / \mathrm{C}$ composite.
\end{abstract}

(Received October 21, 1996)

Keywords: carbon nanotube, carbon 60, plastic deformation, composite, interface structure, transmission electron microscopy, raman spectrum, mechanical property

I. 緒言

近年, カーボン 60 やカーボンナノチューブ等の球款状や 円筒状構造をるつ新炭素物質が注目されている。これらの物 質がもつ高次構造炕起因して電子物性や化学反応性などに幾 つもの興味深い性質が期待されるからである(1)-(5)。ここで はしかしこれら新炭素物質を構造材料として利用することを 考光，両者の力学的性質を問題とする.

カーボン60は炭素原子 60 個がサッカーボール型の構造を とる巨大分子であり，室温で各々の分子を格子点とする面心 立方晶を形成する．結晶化したカーボン60は通常の面心立 方金属と同様なすべり系を持ち，塑性变形火より加工硬化す

†東京大学大学院 (Graduate Student, The University of Tokyo)

计現在：九州工業大学工学部物質工学科(Now at Kyushu Institute of Technology)
る(6) (7)。一般に炭素系材料は比強度, 弾性率が高く, この面 では構造材料として優れた性質を示すが，共有結合性に由来 する硬くて脆いという急の力学的性筫の克服が課題である. したがって，カーボン60結晶の持つ塑性変形性は貴重で, 従来の炭素材料比はない新しい用途が拓がる可能性があ る.

一方, カーボンナノチューブは黒鉛を特改づける面状の炭 素原子の六員環網目を筒状々丸めその両端を五員環構造を配 して半球状に閉じた構造をとる。カーボン60を半分に割っ てその間に六員環網目の円筒党挿入したと考克てよい。ナ， テューブは既存の炭素瀻維と比べ結晶としての完全性が高 く,その構造は一種のひげ結晶と見なすことができる。ナ， チューブに関するシミュレーション計算からは極めて高い弹 性率が理論的に予測された ${ }^{(8)}$. ところが, 先に著者らは, こ のナノチューブに座屈を伴ら特異な様式の塑性変形能を発見 し(9)(10)，炭素系繊維枋料としての応用火新たな可能性を見 
出した。このナノチューブを強化䋐維としてカーボン60結

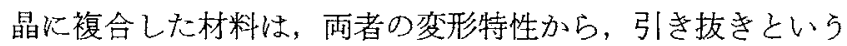
塑性加工による製造が可能であると期待される。これによっ て, 塑性変形能を示す新しいタイプの炭素系複合材料を創製 できる可能性がある.

本研究では，ナノチューブを䋐維強化相とし，カーボン 60をマトリックスとしたカーボンナノチューブ/カーボン60 結晶複合体を作製し, その界面微細組織と力学的性質を評価 すること炕上り，新炭素材料製造に途を拓くための基礎的知 見を得ることを目的とした。

\section{II. 実 験 方 法}

\section{1. ナノチューブ，カーボン 60 ナノ結晶の作製}

本研究で使用したナノチューブ拉よびカーボン60はへり ウ么雾囲気中 $(5.3 \mathrm{kPa})$ で炭素棒 $(99.99 \%)$ をアーク放電 $(25$ $\mathrm{V}, 300 \mathrm{~A})$ させることにより作製した。ナノューブは陰極

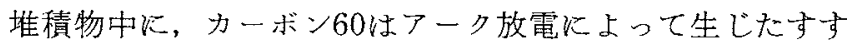
の中に含委れている.ナノチューブは陰極堆積物中の特に筋 状炏生成した組織の表面炕多数生じている. 本研究で怡筋状 組織のみを採取し，エタノールに浸漬後，超音波を印加する ことにより表面のナノチューブを液中に分散させ，上澄み液 としてこれを回収した。最終的に得られる試料はナノチュー ブ(平均長さ：約 $2.1 \mu \mathrm{m}$, 平均直径：約 $15 \mathrm{~nm}$ ) を約 60 vol\%含有している. 一方, カーボン60は他のフラーレン類 とともにトルェンによって抽出し, 液体クロマトグラフィー (UV-8011，東ソ一製)によって分離・精製しな。粉末とし て得られたカーボン60をガス中蒸発法により極微細結晶化

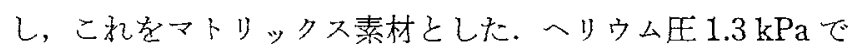
作製した極微細結晶(ナノ結晶)の平均粒径は約 $50 \mathrm{~nm}$ であ る.

\section{2. バルク複合体の作製とその界面組織および力学的性質 の評価}

エタノール中で超音波を印加する湿式混合によりナノチュ ーブの複合量を $40 \mathrm{vol} \%$ とすカーボン 60 ナノ結晶との混 合粉末を作製した。計量はナノチューブとカーボン60の密 度を矢れどれ $2.0 \mathrm{Mg} / \mathrm{m}^{3}, 1.68 \mathrm{Mg} / \mathrm{m}^{3}$ と見積って行った。 混合粉末を真空恒温炉で乾燥させた後, 銀シースに充填し, 室温・大気中でFig. 1 亿示した手順で引抜加工した。引抜 加工で線材の最終径を小さくすること炕よナナチューブの 配向を向上させた．また，作製した陚料は真空中(1.3 Pa)で の加熱処理 (1243 K, $54 \mathrm{ks})$ Kより, 銀シースを除去し, 複 合試料の双が得られるようにした。複合試料の力学的性質 は, 空温・大気中での引張試験に上り評価した。引張試験は インストロン型超微小引張試験機(オートグラフ AGS-D. Type-III，島津製作所製)を用い, Fig. 2 飞示したように 6 本の複合体試料を並べて有機系接着剂で支持板に固定したも のを試験片として行った。クロスへッド速度は $8.3 \mu \mathrm{m} / \mathrm{s}$. と

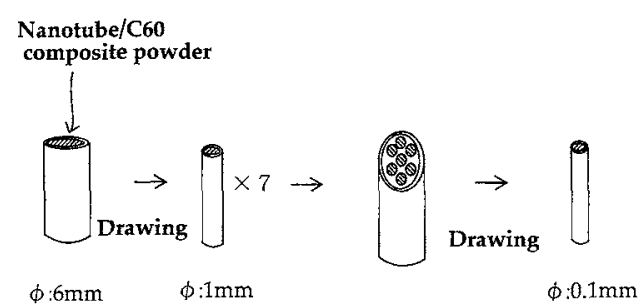

Fig. 1 Processing scheme of carbon nanotube/carbon 60 composite.

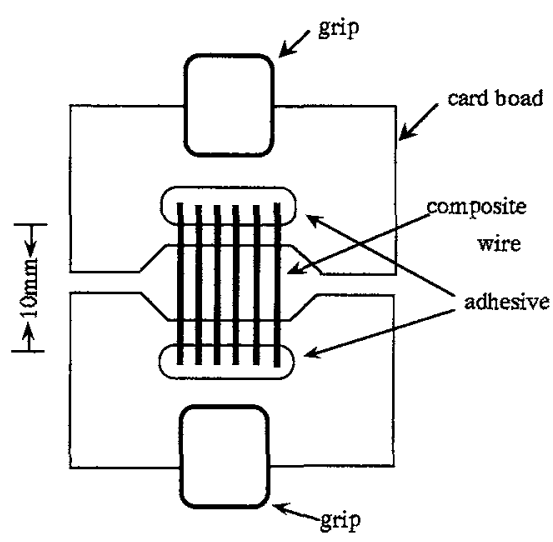

Fig. 2 Schematic diagram of the tensile test specimen.

し，歪みはクロスーッドの变位から求めた．

複合組織の構造はラマン散乱分光分析 (Ga-505)拉上び透 過電子顕微鏡(TEM, JEM-200CX)を用いて評価した。 ラマ ンスペクトルの測定は試料の損傷を防止するため極微弱光励 起炕上り行った。測定条件は励起光: $514.5 \mathrm{~nm}$, レーザー 入力 : $0.1 \mathrm{~mW} / 1 \mu \mathrm{m} \phi$ である.

\section{3. 単繊維複合体の作製とその界面組織および力学的性質 の評価}

㵶維/ートリックス界面の力学的特徵炕関する知見を得る た好単絨維複合体を作製し，構造々強度の両面加検討を行 った. 1 本のナノチューブを内包するカーボン 60 試料は, ナ ノチューブ上にカーボン 60 結晶を直接気相成長させること によって作製した。ナノチューブをカーボン60粉末ととも に石英ガラス管中に真空封入し，炬内の温度勾配(873〜 $723 \mathrm{~K}$ )を利用してナノチューブ上代結晶成長させた。ナノ チューブ/カーボン60界面の微細組織観察はTEMを用いて 行った。また，本実験では炭素㵶維上にカーボン60粗大晶 を成長させた試料も同様にして作製しプルアウト試験によ る荷重-変位曲線の測定から，界面せん断応力を見積った。 炭素縺維は配向性の高いピッチ系高弾性炭素絨維(弾性率： $700 \mathrm{GPa}$, 䋐維径: 約 $10 \mu \mathrm{m}$, 東燃製）を用いた。プルアウ 卜試験は引張試験と同じ条件で行った。Fig. 3 飞試験装置 の概観を示した。 


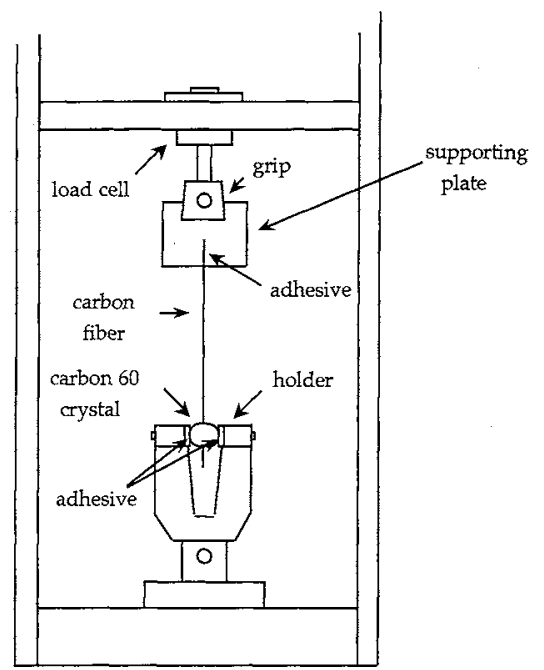

Fig. 3 Schematic diagram of the pull-out tester.

\section{III. 害 験 結 果}

1. 引抜加工で作製した複合強化試料の微細組織と力学的 性梊

\section{(1) 組織配向}

Fig. 4 は引技加工によって作製したナノチューブ/カーボ ン60複合体の断面 SEM 写真である. 直径 $100 \mu \mathrm{m}$ の線材中

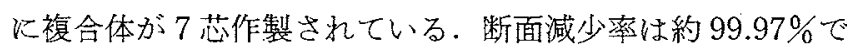
ある、銀シース部分を硝酸で溶解し薄くした後に試料を引張 り破断させ，その先端部を TEM 観察した．複合体中では加 エによって変形したナノチューブが観察されたものの，折損 によるアスペクト比の減少以認められず，また，Fig.5亿 示したように線径を細く絞ったため引抜方向炕良く配向した 組織となっていた。

\section{（2）加熱によるマトリックスの組織変化}

カーボン60結晶は高温度の加熱烧してはあまり安定で

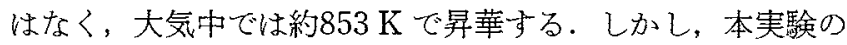
ように周りを銀によって包み込九だ状態では昇華点以上の温 度に加熱してもマトリックス部は安定して存在していた。加 熱処理火より銀シース部を蒸発させた後も，複合体は成形時 の形状を維持していた．Fig. 6 亿そのSEM 写真を示した。

この複合体のマトリックス部についてラマンスペクトルの測 定に上る構造評価を行った．比較のためにグラファイト，ダ イヤモンド，カーポン60結晶についてるとれぞれ測定を行 った. Fig. 7炕示したよら火 $1470 \mathrm{~cm}^{-1}$ 付近にカーボン60 結晶によるピーク成分が僅が認められ，熱処理後もカーボ ン 60 が残存することが確認できた。しかし，グラファイト とダイヤモンドに相当する位置揊広いスペクトルが観測さ れ，加熱処理により，カーボン60結晶が部分的に相変態し たことを示していた。このことは Fig. 8 亿示した TEM 観 察でる示唆されて打り，カーボン60結晶の(111)面之非晶質 相が観察された。

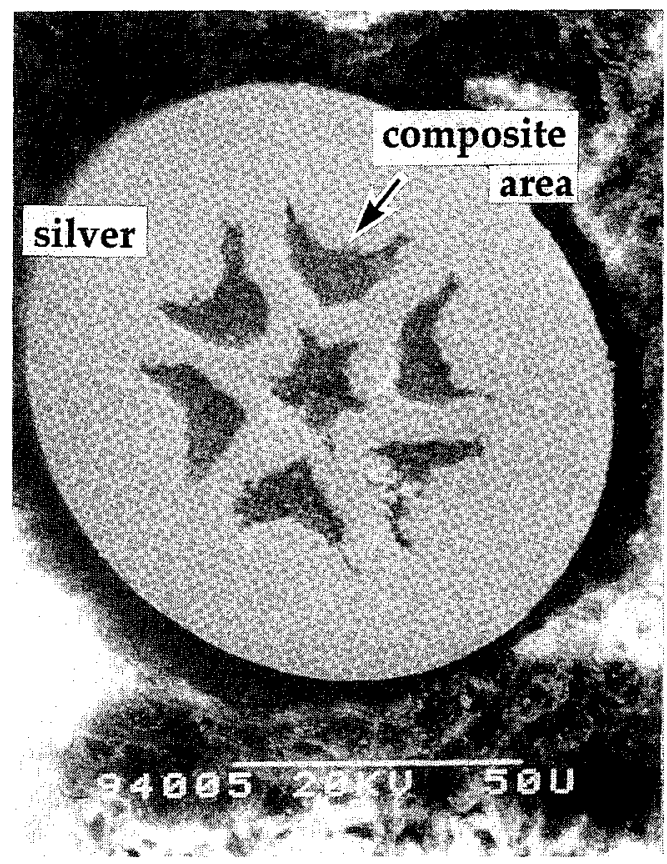

Fig. 4 Cross sectional view of the drawn composite wire.

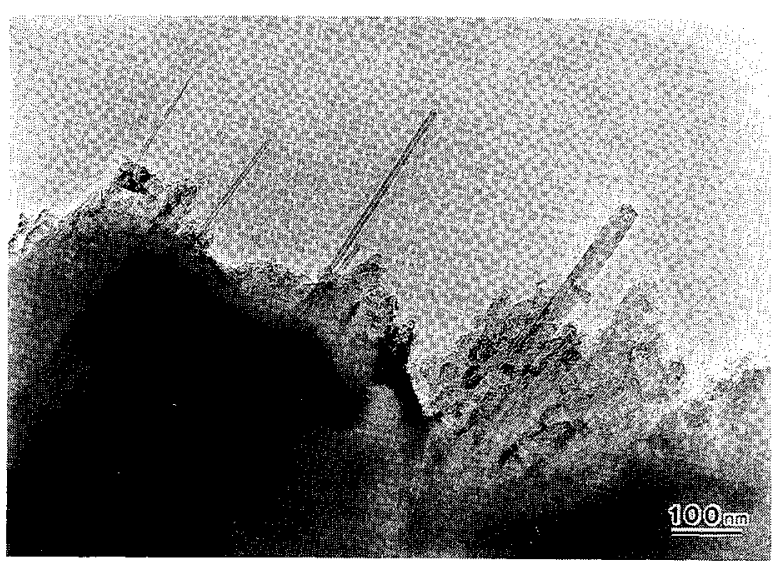

Fig. 5 Transmission electron micrograph of the composite. Carbon nanotubes were aligned along the longitudinal direction of the composite wire.

\section{（3）バルク複合強化試料の引張特性}

Fig. 9 亿本実験で得られた試料の応力-歪曲線を示した。 試料は室温で $10 \%$ 以上の伸びを示し, 破断強度はカーボン 60 多結晶体のそれの約20倍に当たる $18 \mathrm{MPa}$ を記録した。 弾性变形領域は明確ではなく, はっきりとした降伏点は見出 すことができなかった，試料の破断は最大荷重点に達した直

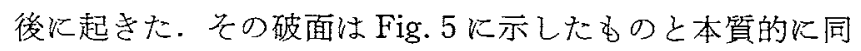
ビで西る、ナノチューブはすべて引き抜けて批，破断社認 めら机なかった。 应，複合体のネッキングは観察されなか った．本実験で得られた破断強度和よび歪はをれぞれ12〜 $30 \mathrm{MPa}, 8 \sim 20 \%$ であり, 4 本の試験片の平均は $17 \mathrm{MPa}$, 11\%でめった. 


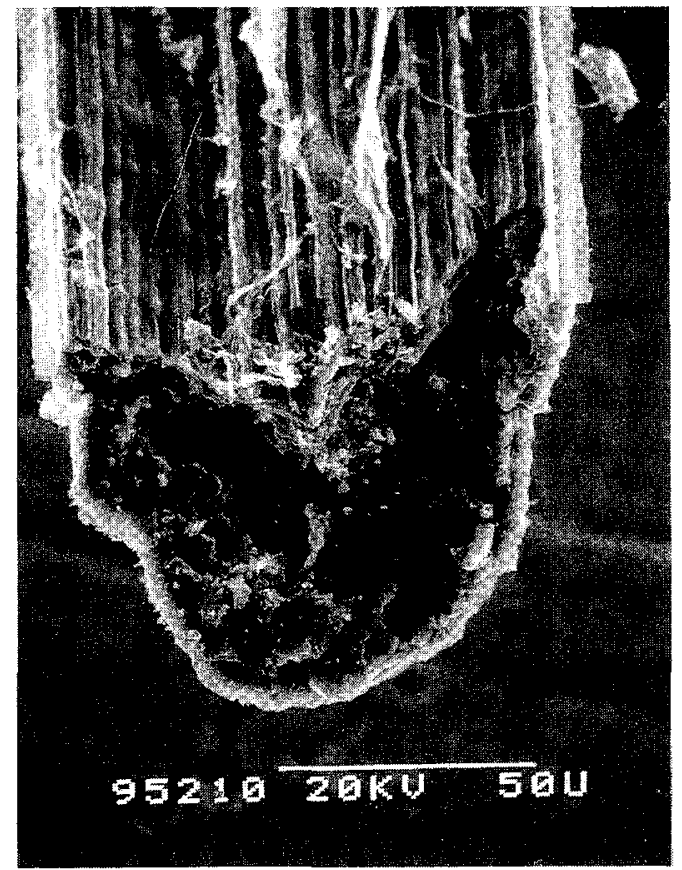

Fig. 6 Scanning electron micrograph of the composite wire heat treated at $1243 \mathrm{~K}$ for $54 \mathrm{ks}$.

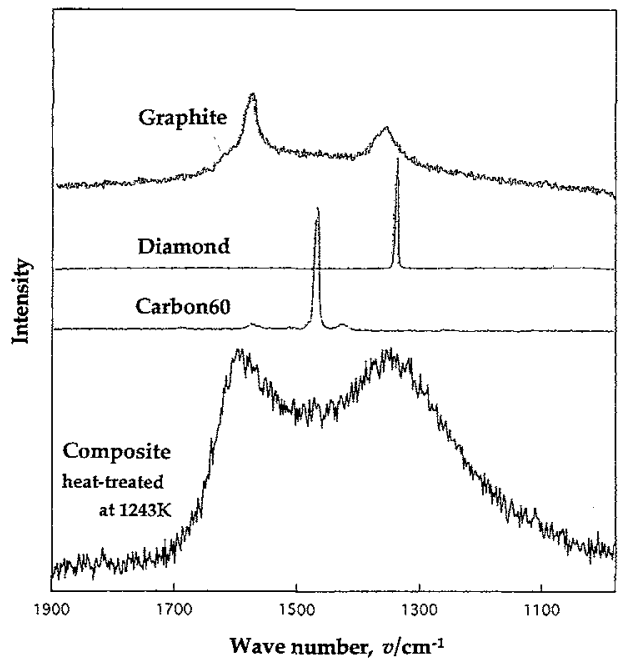

Fig. 7 The Raman spectrum of the composite heat treated at $1243 \mathrm{~K}$.

Spectra of graphite, diamond and carbon60 crystal are shown as references.

\section{2. 気相成長界面の徽細組織と単繊維複合体界面の力学的 性質}

引張試験の結果, この複合試料は最大荷重に達するまでた 10\%を越える大きなひずみを示すことがわかった。これは 従来の崖素系複合村料にはなかった特徴である。この変形挙 動にはマトリックスの力学的性質あるいはナノチューブ/カ 一ボン 60 界面の力学的性貲の関与が考党られる。この複合 試料の特性の起源を明らかにするため，繊維上に直接カーボ

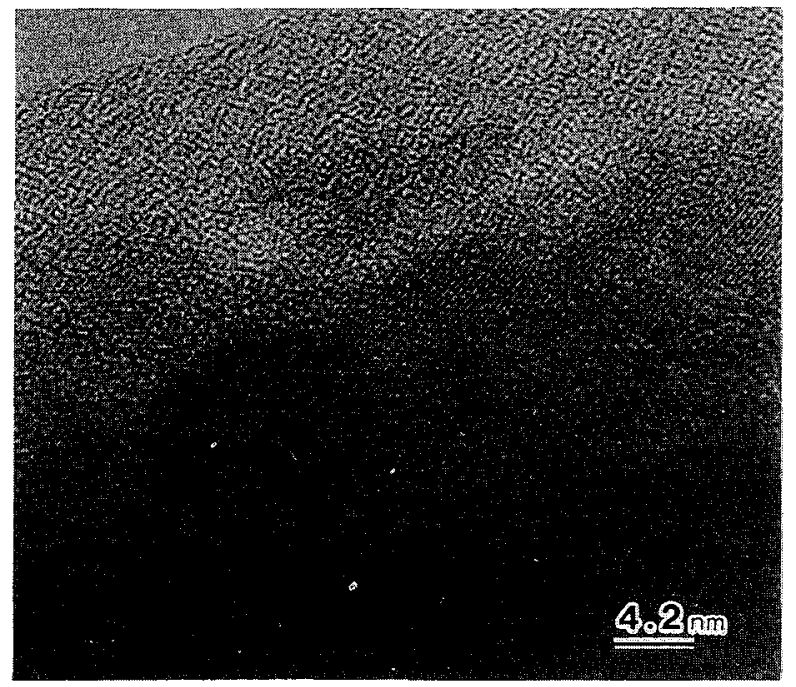

Fig. 8 Transmission electron micrograph of the compoiste heat treated at $1243 \mathrm{~K}$ for $54 \mathrm{ks}$.

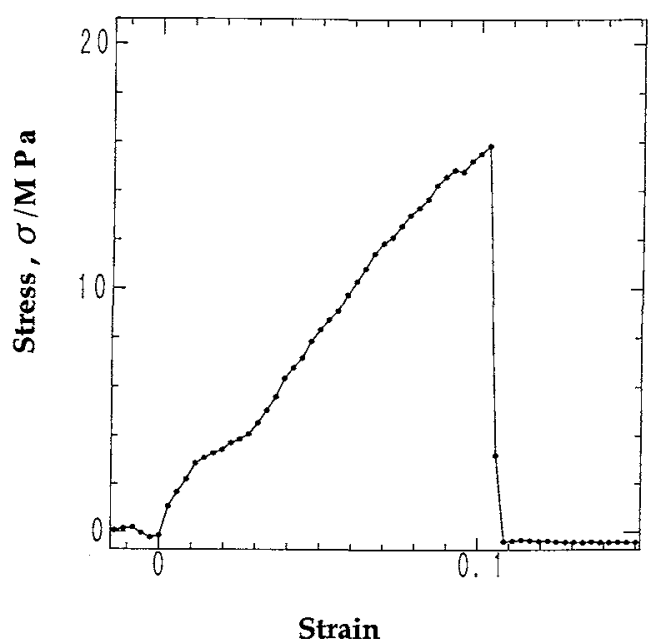

Fig. 9 Stress-strain curve of the heat treated composite.

ン60を成長させた試料を用いて実験した。

ナノチューブ上に成長したカーボン60結晶はバルク体と 同様，面心立方搆造をとる。しかし，ナノチューブが円筒状 であるためエピタキシャル方位関係は Fig. 10 亿示されるよ らにナノチューブの軸方向とカーボン 60 結晶の稠密低指数 朝である〈110〉との平行関係に限定される。

Fig. 11 亿炭素繊維/カーボン60粗大晶複合試料の SEM 観察例を示した，気相法によって成長した数百 $\mu \mathrm{m}$ 数 $\mathrm{mm}$ 角程度のカーボン 60 粗大晶は炭素瀻維を取り囲をよう数珠 状见成長した。炭素絨維/カーボン60界面は䋐維がグラフっ イト底面を表面とするオニオン型高弾性䋐維の場合，ナノチ ューブ上へのそれと良く似てカーボン60結晶の〈110〉方向が 繊維軸に平行となった。

プルアウト試験は炭素㵶維上飞生成したカーボン 60 粗大 晶を試料として行った。ここでは作製した試料のうち，上記 の軸方位関係にある試験片を 3 本選び出して行った。本夷 


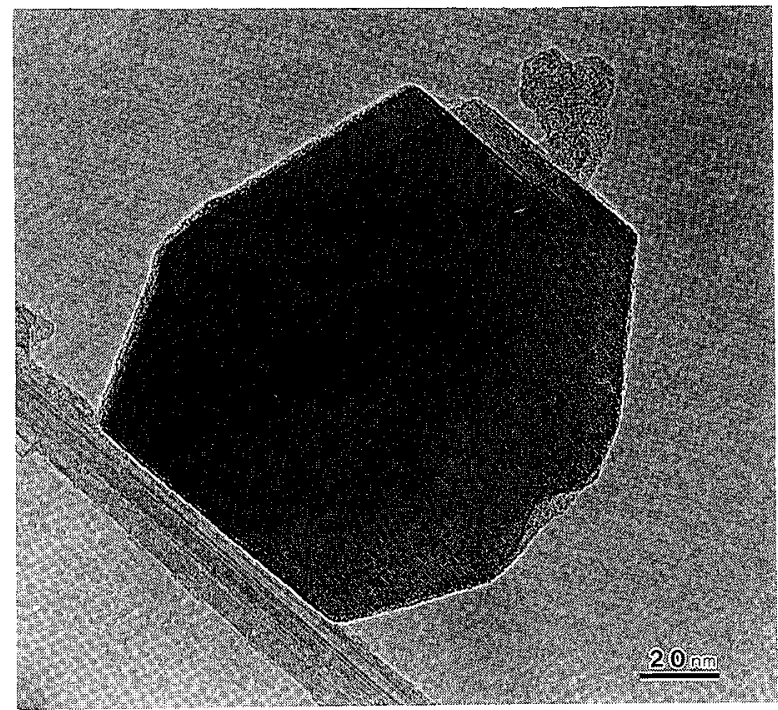

Fig. 10 Electron micrograph of a carbon 60 crystal epitaxially grown on a carbon nanotube.

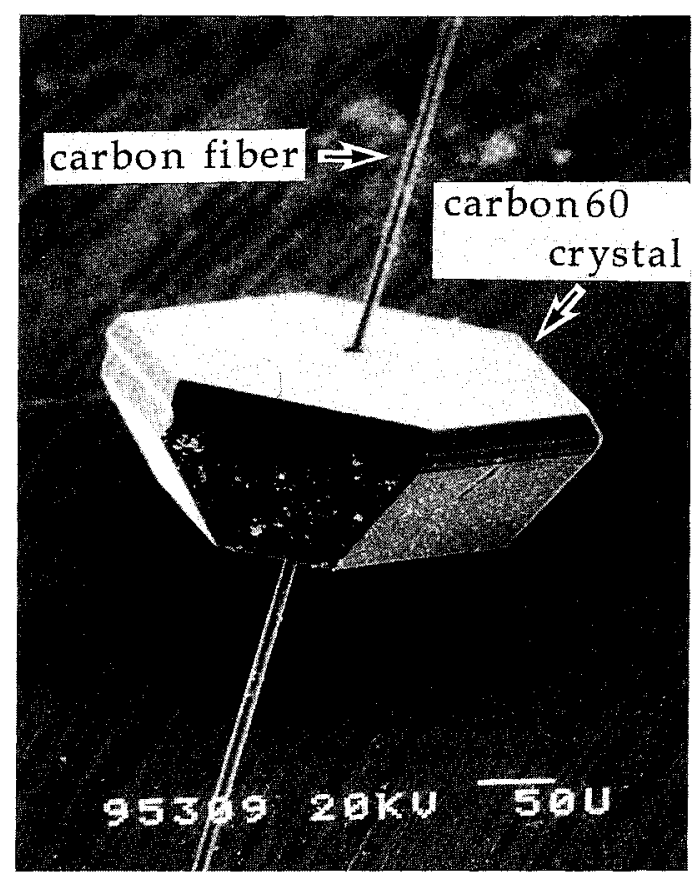

Fig. 11 Scanning electron micrograph of carbon60 crystal grown on a carbon fiber.

験で得られた荷重-変位(L-D)曲線をFig. 12 に示与. L-D 曲 線は, 最大荷重点に達した直後に荷重が急激に低下し，この とき䇛維が引き抜けたことを示していた。この L-D曲線 の最大荷重と炭素䋐維の埋め込文長さから見積もった界面せ 几断応力は約 $4.4 \times 10^{-2} \mathrm{MPa} て ゙$ 西っ．本実験では，繊維 が引き拔汀る際汇特徵的以生ずるスティックスリップと呼ば れる微小な荷重の增減(11)が曲線の精度の範围では認められ なかった. Fig. 13 にプルアウト試験後のカーボン60粗大晶 飞生じた穴の側壁おょび縁周辺部の SEM 写真を示す。図中

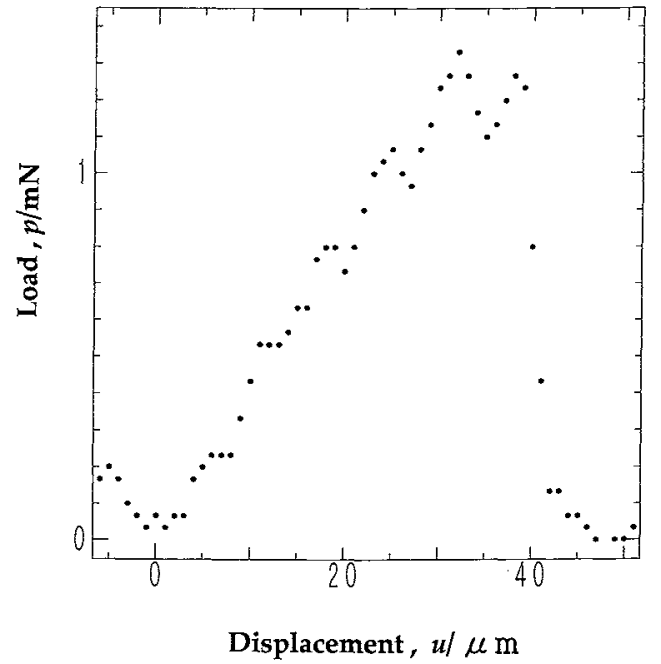

Fig. 12 The road-displacement curve of a carbon fiber/carbon60 composite during the pull-out test.

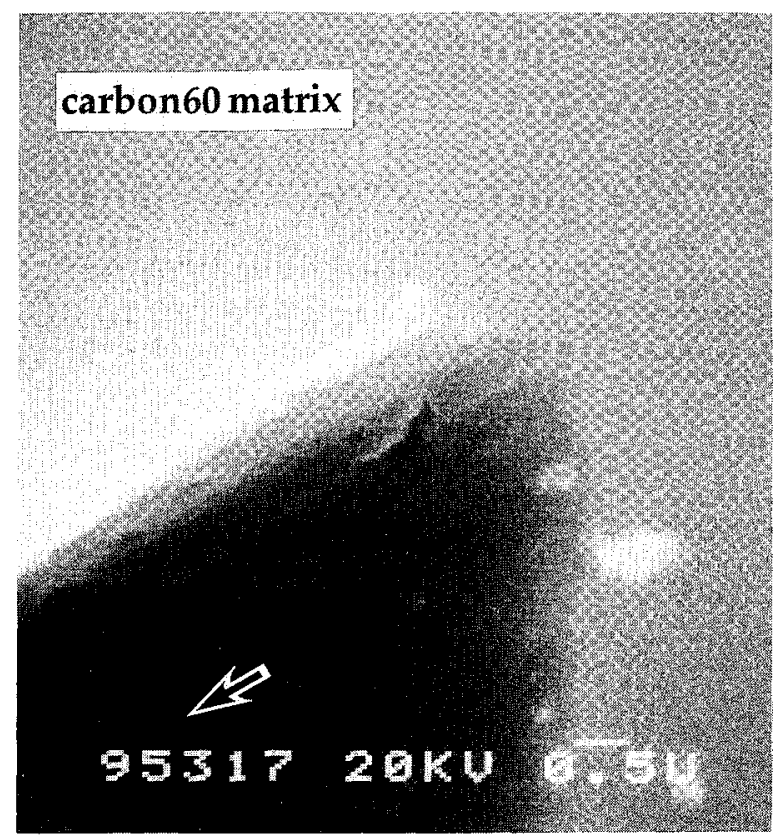

Fig. 13 Scanning electron micrograph of the surface of the interface at the matrix side showing inside the hole made by pulled-out fiber.

An arrow shows the axis direction of fiber.

矢印は䋐維軸方向を示して软り，穴はこの力向に貫通してい る。繊維が引き抜けた後の穴の側壁および縁周辺にはクラッ クやすべり線など塑性変形を示与臣視的な痕跡は観察されな かった．炭素縅維はせん断方向の界面すべりによってそのま ま引き抜けたものと推測された。

\section{N. 考察}

既存の炭素系複合材料は比強度, 弾性率が他の村料と比較 して著しく高いが，瀻維もマトリックスも脆性的であるため 
その伸びは 1〜2\%程度である. 䋊維やマトリックスに既存 の炭美材料とは異なる特性を持つカーボンナノチューブとカ ーボン60を利用したことが 10\%以上の伸びを持つ炭素系複 合体をもたらしたことは間違いない。問題はこの大きな伸び がカーボンナノチューブとカーボン 60 との界面の持つ特異 な構造炕よてもならされたものか，あるいはカーボン60 結晶自体の延性がこれを可能にしたのかである。より特性の 高い複合体を製作する上でこれは重要な項目である，以下に 熱処理後のマトリックスとナノチューブ/カーボン60界面を 対象とし，无の力学的性質への影響を組織学的炕考察した.

\section{1. カーボン 600 相変態とその力学的性質への影響}

結晶粒径を数十 $\mathrm{nm}$ 程度まで極微細化した集合体では塑性 現象への粒界の関与が顕著となる。特に，ナノ結晶化した力 一ボン60結晶集合体では分子間力による弱結合を反映して， 室温での超塑性的な変形挙動が期待できる(7)。しかし，応力 霆曲線の測定，特よび破面観察の結果，伸びに対する結晶粒 の極微細化の影響は明瞭ではなかった。その一因としてマト リックスの相变態による変形能の低下が考光られる。

加工したカーボン 60 結晶は昇華点(約 $853 \mathrm{~K}$ ) 以下での熱 処理ではわずかに回復するのみである(12). 分子自体は $1500 \mathrm{~K}$ 程度まで安定であると見積もられているが，高温度 で熱処理した組織に関しては実験報告が少ない(13)(14)。本実 験におけるラマンスペクトルの湘定执よび TEM 観察の結果 は, 熱処理によりカーボン60結晶がその組織の特徽を徐々 消失し，代わり火結合状態が変化した非晶質相を生じたこ とを示唆している。カーボン60はグラファイト構造が末発 達な準安定構造とみなせることから，これを熱的に活性化す ることによりカーボン60分子が崩壊し、グラファイト構造 やダイヤモンド構造へと結合状態が変化することが十分火予 想される。実際，カーボン600高温・高王実験ではダイけ モンドの合成が報告されている(15)(19).

相変態によってカーボン60結晶とは異なる非晶質相が生 ごたこと，また，非晶質相によってカーボン60結晶の粒界 すべり変形が抑止されたことがマトリックスの硬化をるたら した原因であると考えられる。しかし，これまでに報告され ているカーボン $60 ナ$ ノ結晶集合体の変形挙動(7)は完全な超 塑性現象を示しているとは言えず，粒径，密度さらには熱処 理後の結合状態などマトリックスの力学的性質に影響を及活 す組織学的要因等について詳細な検討を加える必要があると 考光る。

\section{2. 䋐維-マトリックス界面の構造とその力学的性質への 影響}

熱処理後のマトリックスの組織と破面の観察結果から，複 合試料の伸びはマトリックスの塑性よりもむしろ䋐維/マト リックス間の力学的特徽の寄与が大きいと考光られた。乙こ で，界面の構造とプルアウト試験の結果からその仮定を組織 学的に検討した。
カーボン60結晶の格子定数 (格子定数 : $1.417 \mathrm{~nm}$, 最近接 分子間距離 : $1 \mathrm{~nm}$ )がグラファイト底面のそれ(格子定数： $\mathrm{a}=0.246 \mathrm{~nm}, \mathrm{C}-\mathrm{C}$ 原子間距離 $: 0.142 \mathrm{~nm}$ ) と比へ厈倒的に大 きいので，界面がもし平面であったとしてもェピタキシャル の効果による界面エネルギーの低下は小さいと予想される。 また，グラファイト基盤は，金属を基盤とした場合 ${ }^{(20)(21)}$ K 比べカーボン60との相互作用が弱く，Si 基盤で報告(22)され ているようなダングリングボンドのトラップサイトとなると ころがないことなどる長周期なェピタキシャル関係を持りに くい界面であることを示唆している.

実際K界面の TEM 観察結果をもとKグラフォイト底面上 のカーボン60の分子配列を模式図化してみると Fig. 14 に 示したような幾何学的配置となる。常温・常王に执いて結晶

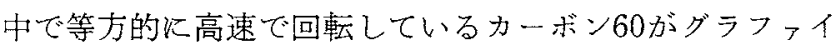
卜底面上では兀電子系の相互作用によりとの回転を止めてい ると考劣と, 界面のエピタキシャル関俰はむしるカーボン 60分子の六員環とグラフォイトの六貝環との対応といった 局所領域に和いて成り立っている可能性がある。しかし，ナ ノチューブは円筒状であり午の直径は $20 \mathrm{~nm}$ 程度にすぎな いから，局所的エピタキシャル関係がもし存在してもカーボ ン60結晶のセル単位にして $2 \sim 3$ 個の範用に限られるため, やはりエピタキシャルの効果はェネルギ一的に微弱であると 予想される。実際，炭素䋐維/カーボン60粗大晶のプルアウ 卜試験では界面のせん断すべり応力が小さく，繊維の引き技 けにはマトリックスの塑性変形を伴っていないことが実験的 に得られている。ナノチニーブ/カーボン60結晶に敌いても 同样住界では相互作用が弱く，常温で活性であると考方ら

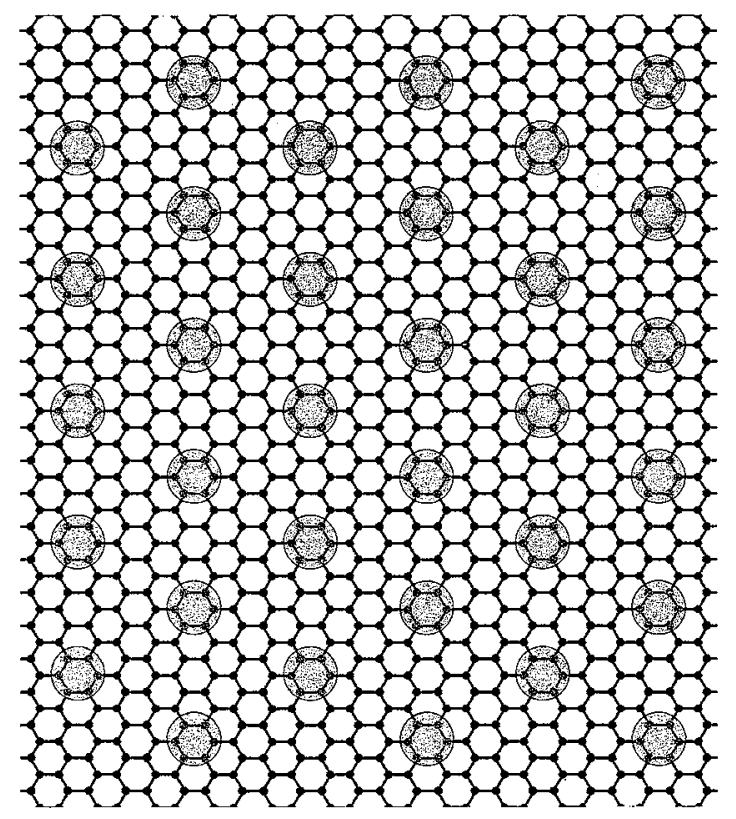

Fig. 14 Comparison of lattice spacings at the interface between carbon 60 and carbon nanotube.

Shaded circles represent the configuration of carbon60 (111) plane on carbon nanotube. 
れこれが纎維/マトリックス界面のせん断すべり変形を可 能にした要因となったものと推論された，高配向性熱分解グ ラファイト基盤炕蒸着したカーボン60の走查型トンネル影 微鏡(STM) 観察からは，カーボン600分子配列は基盤の影 響を受けにくく，また，カーボン60分子は室温に打いても 基盤上を容易に移動することが報告されている(23)(24)。この ことはカーボン60結晶とグラファイトとの界面では強固な 結合を持たず，すべり変形を起こしやすい界面であることを 示唆している. 界面の特性について定量的な知見を得るため にはナノチューブ/カーボン600界面エネルギーとカーボン 60 移動伴ら界面ェネルギー変化についての情報を得る ことが必要である。現在，計算機支援による検討を試みて拉 り，ここで得られた結果から見積もられる界面せ九断応力と 本実験結果とを比較することで界面強されついての定量的な 検討が行壳るものと期待される。

一方，グラファイト底面とカーボン60分子との間の弱い 相互作用を考光ると，界面上汇あるカーボン60分子が自由 回転を維持していることも考光られる。この場合，分子へア リング的な役割を果たしている可能性もあり、トライボロジ 一の観点からも與味深い.グラファイト底面上でのカーボン 60分子の挙動和よび原子レベルでの界面構造の解明には今 後 TEM, STM 等の局所解析技術を総合したより詳細な議諭 か必要となると考光る.

\section{V. 総 括}

本研究ではカーボンナノチューブを繊維として用い，カー ボン60結晶を強化することを目的として基礎的検討を行。 た，得られた結果は以下の通りである。

（1）銀シースに充填し，引抜加工法によって作製したナ， テューブ/カーボン60ナノ結晶複合体には折損したナノチュ ーブは見られず，引き抜き方向火良く配向した理想的な繊維 強化組織が得られていた。

（2）上記複合体を真空中， $1243 \mathrm{~K}$ で加熱処理して銀を蒝 発除去した後の応力-歪曲線は，この細線が $10 \%$ 以上の破断 伸びとカーボン 60 結晶の約 20 倍の破断強度を持つことを示 した，従来の炭素材料とは異なる機械的特性を持つ新炭素物 筫を利用することで延性の大きい炭素系複合材料の創製が可 能であることが示された。

（3）複合体の力学特性の起源を繊維/マトリックス界面に 求め，これを気相法によって作製した単瀻維複合体を用い， 強度と構造の両面から検討した。 その結果, 単瀻維複合体で は界面すべりを主機構とする引き抜き夜形が起こり，これが 複合体の伸びに寄与しているものと推諭された。

（4）また，界面の構造解析により，繊維/マトリックス間
に局所的エピタキシャル関係が存在してるとの効果による界 面エネルギーの低下は小さいと予想され, 界面が常温で活性 であることがすべり変形を可能炕した要因として考えられる ことを示した。

本研究を進めるに当たり有益な助言を頂いた東京大学生産 技術研究所の香川 豊助教授，また，線材加工にご協力頂い た昭和電線電纜(树)長谷川隆代氏，小林公樹氏火心から感謝 いたします。

\section{文献}

（1）石田尚行, 田中建次郎, 古館貴雄, 野上隆, 黒野定, 大橋 守: 第6 回 C60総合シソポジム, (1991), 154.

(2) P. J. Krusic, E. Wasserman, B. A. Parkinson, B. Malone, E. R. Holler, P. N. Keizer, J. R. Morton and K. F. Preston: J. AmChem. Soc., 113(1991), 6274.

(3) S. Saito and A. Oshiyama: Phys. Rev. Lett., 66 (1991), 2637.

(4) R. Saito, M. Fujita, G. Dresselhaus and M. S. Dresselhaus: Phys. Rev., B46(1992), 1804.

( 5 ) K. Okahara, K. Tanaka, H. Aoki, T. Saito and T. Yamabe: Chem. Phys. Lett., $219(1994), 462$.

（6）加藤健夫, 末永和知, 高山敬行, 伊藤邦夫, 石田洋一：日本 金属学会誌，57(1993), 1101.

（7）禾永和知, 田中全人，加藤煡夫, 高山敬行, 伊藤丮夫, 石田 洋一：日本金属学会誌，57(1993), 1103 .

(8) G. Overney, W. Zhong and D. Tomanek: Z. Phys. D, 27(1993), 93.

(9) Y. Ishida, T. Hayashi, H. Ichinose, T. Kuzumaki and K. Ito: ICEM13, LES Editions de physique, Paris, (1994), 9.

（10）暮巻 徹, 林 卓哉, 市野瀨英喜, 宮澤薰一, 伊藤邦夫, 石田洋一：日本金属学会誌，60(1996)，9.

（11）本田絃一，香川 豊：日本金属学会誌，58(1994), 91

(12) 小川啓輔：東京大学修士論文 (1996).

(13) J. L. Hodeau, J. M. Tonnerre, B. B. Fabre, M. Nunez, Regueiro, J. J. Capponi and M. Perroux: Phys. Rev., B50, 14(1994), 10311.

(14) M. N. Regueiro: Modern Phys. Let., B6. 19(1992), 1153.

(15) H. Hirai and K. Kondo: Proc. Jpn. Acad., 67, SerB (1991), 22.

(16) M. N. Regueiro, P. Monceau and J. L. Hondeau: Nature, 355 (1992), 237

(17) V. Paillard, P. Melinon, V. Dupuis, A. Perez, G. Guiraud and J. Fornazero: Phys. Rev., B49, 16(1993), 49.

(18) Y. Iwase, T. Arima, R. M. Fleming, T. Siegrist, O. Zhou, R. C. Hadden, L. J. Rothberg, K. B. Lyons, H. L. CarterJr., A. F. Hebard, R. Tycko, G. Dabbagh, J. J. Krajewski, G. A. Thomas and T. Yagi: Science, 264(1994), 1570.

(19) H. Hirai and K. Kondo: Phys. Rev., B51, $21(1994), 51$.

(20) J. K. Gimzewski, S. Modesti, Ch. Gerber and R. R. Schlitter: Chem. Phys. Lett., 213(1993), 401.

(21) T. David, J. K. Gimzerwski, D. Purdie, B. Reihl and R. R. Schlitter: Phys. Rev. B50, 8(1994), 5810.

(22) T. Hashizume, K. Motai, X. D. Wang, H. Shinohara, Y. Saito, Y. Maruyama, K. Ohno, Y. Kawazoe, Y. Nishina, H. W. Pickering, Y. Yuk and T. Sakurai: Phys. Rev. Lett., 71(1992), 2959.

(23) Y. Maruyama, T. Inabe, H. Ogata, H. Hoshi, N. Nakamura, Y. Mori, Y. Achiba, S. Suzuki, K. Kikuchi and I. Ikemoto: Physi$\mathrm{ca}, \mathrm{C} 185$ (1991), 413.

（24）束永和知，加藤健夫，有沢俊一，原重樹，山本良一，营巻 徹, 市野濑英喜, 伊藤邦夫, 石田洋一：日本金属学会春期大 会講演概要, (1993), 253 . 